\section{NEW RECORDS OF ROTIFERS (ROTIFERA: EUROTATORIA) FROM DEEPOR BEEL - A RAMSAR SITE OF INDIA WITH AN UPDATE ON ITS RICH ROTIFER DIVERSITY}

\author{
B.K. Sharma ${ }^{1}$ \& Sumita Sharma ${ }^{2}$ \\ ${ }^{1,2}$ Freshwater Biology Laboratory, Department of Zoology, North-Eastern Hill University, Shillong, Meghalaya 793022, India \\ ${ }^{1}$ probksharma@gmail.com (corresponding author), ${ }^{2}$ sumitasharma.nehu@gmail.com
}

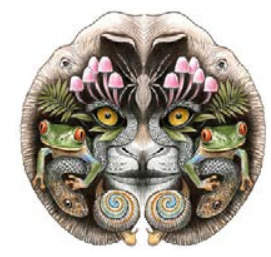

ISSN 0974-7907 (Online) ISSN 0974-7893 (Print)

OPEN ACCESS
Abstract: Plankton samples collected from Deepor Beel (a Ramsar site), during July 2011 to June 2013, revealed 155 species of Rotifera, belonging to 35 genera and 20 families. Of these, 16 species belonging to eight genera and seven families are new records to the rotifer fauna of this wetland of northeast India. Our observations raise the total richness of the phylum known till date from this important floodplain lake (beel) of the Brahmaputra river basin to 171 species and thus highlight its biodiversity value as one of the globally rich Rotifera habitats. The updated list is interesting for following meta-analyses of rotifer occurrence in this only well sampled freshwater ecosystem of the Indian sub-region.

Keywords: Meta-analyses, new records, rich habitat, tropical wetland

Deepor Beel, the sole well sampled floodplain lake (beel) and Ramsar site of India, was identified as an interesting ecosystem of Asia for Rotifera diversity (Sharma \& Sharma 2012). Our recent limnological survey (July 2011-June 2013) of this wetland revealed 155 rotifer species thus added 16 new species records and further affirmed the biodiversity value of this important beel of the Brahmaputra River basin of Assam vis-a-vis the role of sampling. The present study comments on various new records with a note on update on Rotifera diversity of Deepor Beel. We provide an

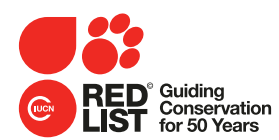

inventory of 171 species known till date from this Ramsar site for following meta-analyses of occurrence of the taxon.

\section{MATERIALS AND MetHOdS}

The present study is based on plankton samples collected, between July 2011 and June 2013, from Deepor Beel $\left(91^{\circ} 35^{\prime}-91^{\circ} 43^{\prime} \mathrm{E}\right.$ \& $26^{\circ} 05^{\prime}-26^{\circ} 11^{\prime} \mathrm{N}$; area: $40 \mathrm{~km}^{2}$; altitude: $42 \mathrm{~m}$ ) located in Kamrup district of Assam State of northeastern India (Fig. 1 A-B). This floodplain lake is covered with several aquatic macrophytes namely Hydrilla verticillata, Eichhornia crassipes, Vallisneria spiralis, Utricularia flexuosa, Trapa bispinosa, Euryale ferox, Najas indica, Monochoria hastaefolia, Ipomea fistulosa, Hygrorhyza aristata, Polygonum hydropiper and Limnophila sp. Qualitative plankton samples were collected monthly by towing nylobolt plankton net (\#50 $\mu \mathrm{m}$ ) from six sampling stations and were preserved in 5\% formalin. On each sampling occasion, aquatic vegetation was disturbed before towing plankton net to facilitate collection of planktonic and semi-planktonic rotifers. All samples were screened; the rotifer taxa were isolated, mounted in polyvinyl alcohollactophenol mixture and were observed with a Leica DM 1000 image analyzer. Rotifer species were identified following Koste (1978), Segers (1995), Sharma (1998) and Sharma \& Sharma $(1999,2000,2008,2013)$. The reference

DOI: http://dx.doi.org/10.11609/JoTT.04044.7011-6 | ZooBank: urn:Isid:zoobank.org:pub:35857A8D-5200-49A0-9E8B-EFDF9B43086C

Editor: Rajashekhar K Patil, Mangalore University, Mangalore, India.

Date of publication: 26 March 2015 (online \& print)

Manuscript details: Ms \# 04044 | Received 26 May 2014 | Final received 20 February 2014 | Finally accepted 27 February 2015

Citation: Sharma, B.K. \& S. Sharma (2015). New records of rotifers (Rotifera: Eurotatoria) from Deepor Beel - a Ramsar site of India with an update on its rich rotifer diversity. Journal of Threatened Taxa 7(3): 7011-7016; http://dx.doi.org/10.11609/JoTT.04044.7011-6

Copyright: (C Sharma \& Sharma 2015. Creative Commons Attribution 4.0 International License. JoTT allows unrestricted use of this article in any medium, reproduction and distribution by providing adequate credit to the authors and the source of publication.

Funding: Ministry of Environment \& Forests (Govt. of India) sponsored project No. 22018-09/2010-CS (Tax).

Competing Interest: The authors declare no competing interests.

Acknowledgements: The samples for this study are collected with the support of the Ministry of Environment \& Forests (Govt. of India) sponsored project No. 22018-09/2010-CS (Tax). The senior author is thankful to the Head, Department of Zoology, North-Eastern Hill University, Shillong for necessary facilities. The senior author is thankful to Messer's M.K. Hatimuria and K. Sounii Pou for help in field collections. We thank our anonymous reviewers for useful comments. 


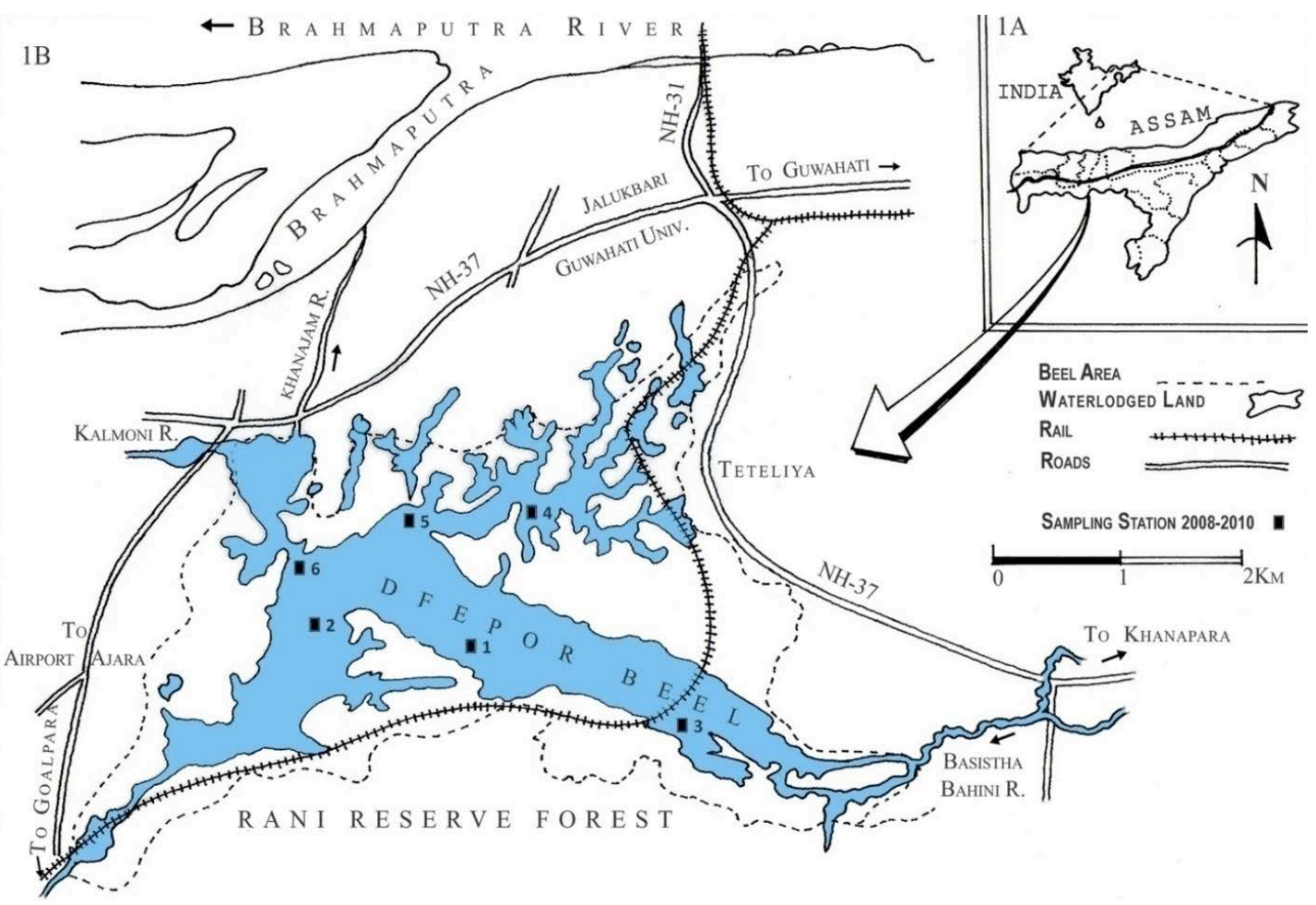

Figure 1. 1A - Location of Deepor Beel; 1B - sampling sites (the six sampling are the same as sampled during our 2008-2010 survey) (after Sharma \& Sharma 2012)

collections were deposited in the holdings of Freshwater Biology Laboratory, Department of Zoology, North-Eastern Hill University, Shillong.

\section{RESULTS}

Our collections revealed 155 rotifer species including 16 new records and raised the tally of our earlier list vide Sharma \& Sharma (2012) to 171 species; a systematic list of the updated species inventory of Deepor Rotifera is presented in Appendix 1. Brachionus kostei (Image 1), Colurella adriatica, C. colurus, Euchlanis meneta (Image 2), Lecane bifurca (Image 3), L. rhenana (Image 4), L. rhytida (Image 5), L. undulata (Image 6), Lepadella lindaui (Image 7), L. quinquecostata (Image 8), L. triba (Image 9), L. vandenbrandei (Image 10), Mytilina michelangellii (Image 11), Trichocerca scipio (Image 12), T. weberi (Image 13) and Wolga spinifera (Image 14) are new additions to the rotifer fauna of this Ramsar site. Sixteen species, including those of three sessile genera of the Flosculariidae, listed earlier from this floodplain lake, are not observed in our current collections. Brachionus caudatus var. personatus is allocated to B. ah/stromi following Giri \& De Paggi (2006).

\section{REMARKS}

One-hundred-and-fifty-five species, belonging to 35 genera and 20 Eurotatorien families, observed presently from Deepor Beel reveal speciose Rotifera assemblage and reiterate our hypothesis (Sharma \& Sharma 2012) on habitat diversity and environmental heterogeneity of this Ramsar site. This report adds 16 species, belonging to seven families and eight genera, as new records to our earlier list (Sharma \& Sharma 2012), thereby, raising the richness of the Phylum known from Deepor Beel to 171 species. Total richness comprises $\sim 71.0 \%$ and $\sim 42.0 \%$ of the rotifer species known till date from northeastern India (NEI) (Sharma \& Sharma 2014a) and India (B.K. Sharma unpublished), respectively and, hence, indicate biodiversity value of this Ramsar site as one of the globally rich freshwater ecosystems for diversity of Rotifera notwithstanding an estimate of occurrence of +210 species of the taxon in the tropical lakes (Dumont \& Segers 1996). The latter estimate, based mainly on certain data from Africa, Brazil and Australia, needs reconsideration on tropical lakes in Asia and Southeast Asia particularly in light of the relatively well studied Indian and Thai Rotifer faunas. The rich rotifer diversity of this Ramsar site supports hypothesis of Segers et al. (1993) indicating (sub) tropical floodplains to be the world's rotifer rich habitats. In general, high richness of Rotifera in Deepor beel is attributed primarily to the rotiferologist effect (Fontaneto et al. 2012) though our earlier (Sharma \& Sharma 2005b, 2011) and present new additions are partly the result of the extensive sampling. 


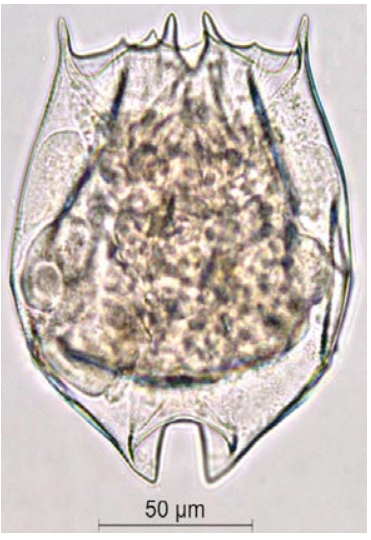

Image 1. Brachionus kostei Shiel (lateral view)

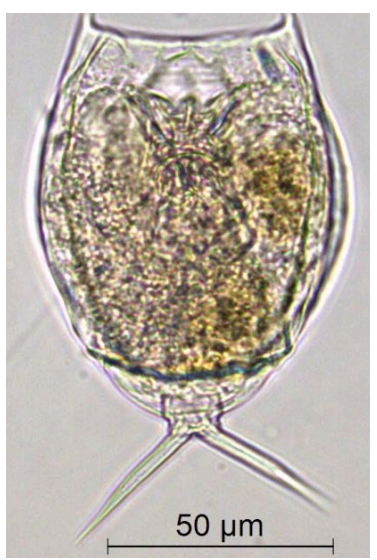

mage 5. Lecane rhytida Harring \& Myers (dorsal view)

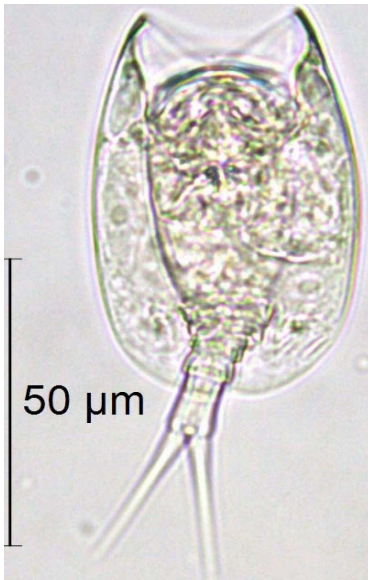

Image 9. Lepadella triba Myers (ventral view)

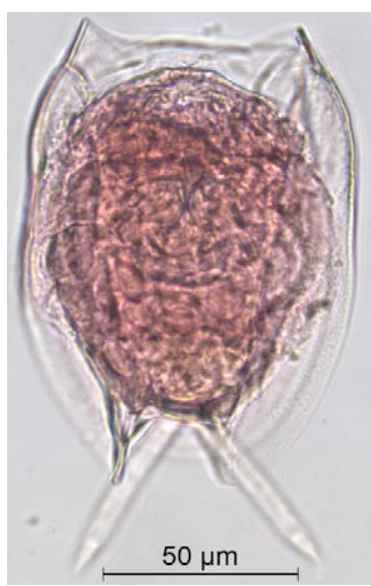

Image 2. Euchlanis meneta Myers (dorsal view)

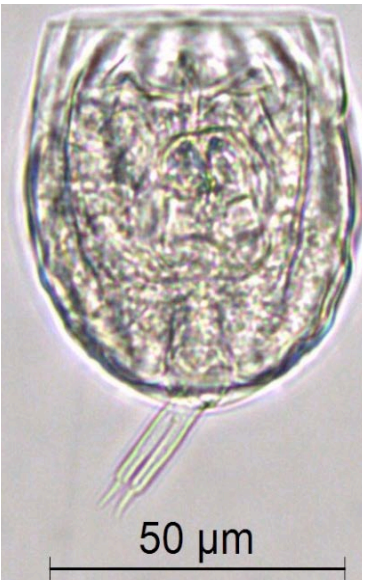

Image 6. Lecane undulato Hauer (dorsal view)

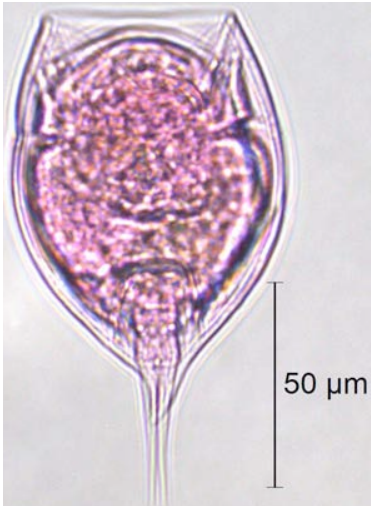

Image 10. Lepadella vandenbrandei Gillard (ventral view)

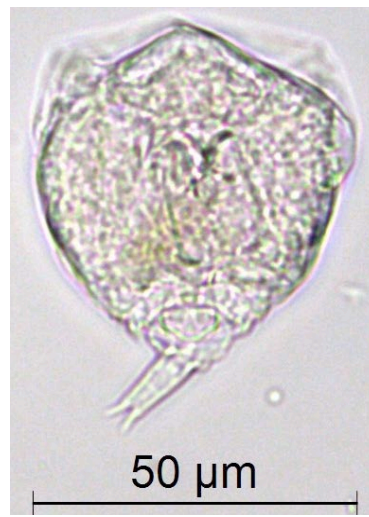

Image 3. Lecane bifurca (Bryce) (ventral view)

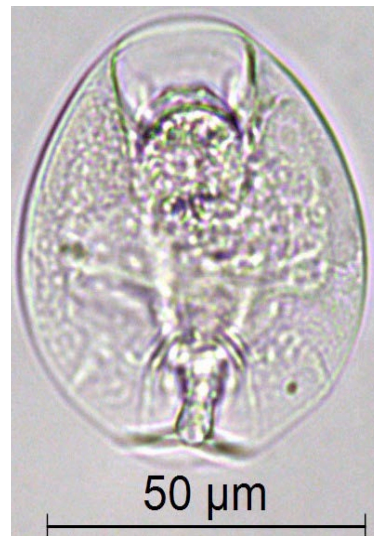

Image 7. Lepadella lindaui Koste (ventral view)

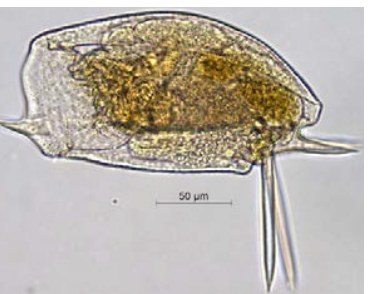

Image 11. Mytilina michelangellii Reid \& Turner (lateral view), after Sharma \& Sharma (2014c)

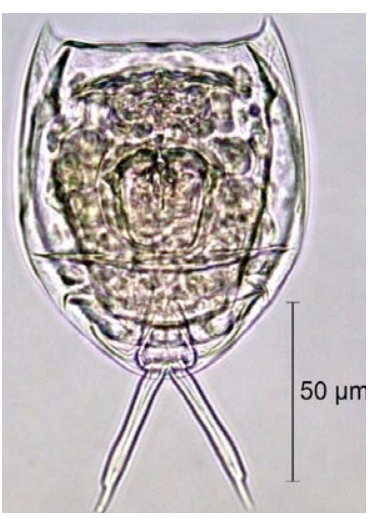

Image 4. Lecane rhenana Hauer (ventral view)

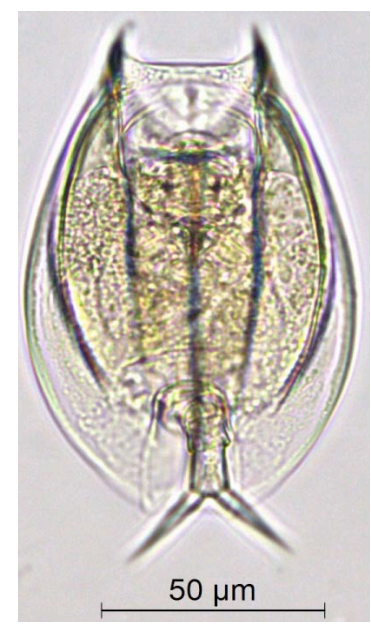

Image 8. Lepadella quinquecostata (Lucks) (dorsal view)

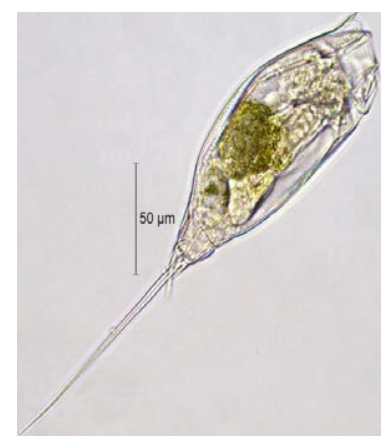

Image 12. Trichocerca scipio (Gosse) (lateral view) 


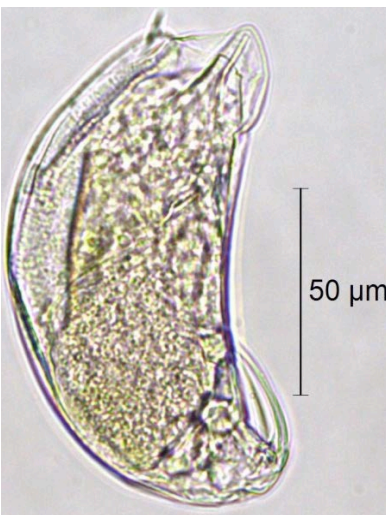

Image 13. Trichocerca weberi (Jennings) (lateral view)

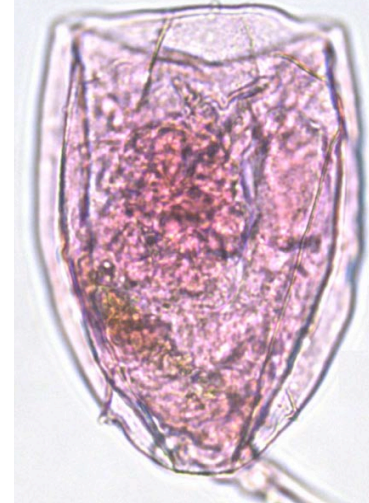

$50 \mu \mathrm{m}$

Image 14. Wolga spinifera (Western) (dorsal view)
Of the new additions, Brachionus kostei, Mytilina michelangellii and Lecane rhenana are biogeographically interesting elements. The report of the Australasian B. kostei merits special mention; it is now known to occur beyond its classical distribution limits in north-east China (Segers 2007) as a possible example of introduction. This brachionid is observed so far from the floodplains of the Brahmaputra River basin (Sharma 2004, 2014; Sharma \& Sharma 2014a,c). M. michelangellii was originally described from Brazil (Reid \& Turner 1988) as subspecies of $M$. ventralis; it is presently retained as a distinct species following its resurrection by Pourriot (1996). This species is characterized by lack of any postero-dorsal spine and restricted global distribution than the cosmopolitan M. ventralis. Segers (2007) indicated distribution of $M$. michelangellii limited to Afrotropical and Neotropical region while Sa-Ardrit et al. (2013) listed it from Thailand based on the sole report by Jithland \& Wongrat (2006). Sharma \& Sharma (2014c) recently extended its distribution to the Indian sub-region. This species is so far examined only from Deepor Beel with possibility of extension of its distribution elsewhere in NEI (B.K. Sharma pers. comm.).

The tropicopolitan Lecane rhenana is another recent addition (Sharma \& Sharma 2014c) to the rotifer fauna of India. This lecanid is known from the African, Neotropical and Palaearctic regions (Segers 2007) while it is reported from the Oriental region from Thailand (Sa-Ardrit et al 2013) and Cambodia (Meas \& Sanoamuang 2010). The lateral margins of dorsal plate of our specimens reach the head aperture margins and hence deviate from original description of the taxon thus supporting the remarks by Segers (1995) on "confused taxonomy" of this species. We agree with Segers (loc cit.) and Jersabek and Leitner (2013) on "unlikely synspecificity of L. sibina and L. rhenana" as proposed by Koste (1978).
Colurella adriatica, C. colurus, Lecane bifurca, L. rhytida, L. undulata, Lepadella lindaui, L. quinquecostata, L. triba, L. vandenbrandei, Trichocerca scipio, T. weberi and Wolga spinifera are other new additions to Deepor Rotifera. Interestingly majority of these species are characterized by their occurrence restricted to NEI. The paleotropical Lepadella vandenbrandei is recently added to the Indian Rotifera from the wetlands of Majuli River Island, upper Assam (Sharma 2014) while Lecane rhytida and L. undulata are also recent reports based on our collections from NEI (Sharma \& Sharma 2014b). Lepadella lindaui and $L$. quinquecostata are known from the floodplains of Assam (Sharma 2004) while Trichocerca scipio is reported from Assam (Sharma \& Sharma 2005a) as T. jenningsi which is a junior synonym of the former (Segers 2001). Euchlanis meneta and Wolga spinifera, two additions to NEI (Sharma \& Sharma 2014a, 2014b), are examples of disjunct regional distribution in India. The former is so far known from the Kashmir Himalayas (Edmondson \& Hutchinson 1934) and Andhra Pradesh (Dhanapathi, 1976), and its report from Gujarat (Dhuru et al. 2003) lacks validation. W. spinifera is, however, observed from the Yamuna River at Delhi (Sarma 1988) and Tamil Nadu (Sharma and Sharma 2009).

Following this biodiversity update, the most speciose Eurotatorien families Lecanidae $>$ Lepadellidae $=$ Brachionidae > Trichocercidae comprise $\sim 70.0 \%$ of the rotifer richness known from this Ramsar site. Further, three littoral-periphytonic genera Lecane (47 species) > Lepadella (22 species) > Trichocerca (17 species), together, include $\sim 50.3 \%$ species of Deepor Rotifera. The relative consistency of the importance of three periphytic monogonont genera in our present collections ( $\sim 52.0 \%)$ as well as our earlier reports from this Ramsar site ( $45.5 \%$ vide Sharma \& Sharma 2005b; 50.6\% vide Sharma \& Sharma 2012) support hypothesis of Green (2003) on the possibility of assemblage rules for the periphytic community. Interestingly, the stated significance broadly concurs with their percentage composition in Rotifera from the floodplains of Niger delta (Segers et al. 1993), Broa reservoir, Brazil (Segers \& Dumont 1996), River Nan, Thailand (Sanoamuang 1998), Bolivia (Segers et al. 1998) and Okavango Delta of South Africa (Green 2003). This generalization is also supported by our other reports from the floodplains of the states of Assam (Sharma 2005; Sharma \& Sharma 2008) and Manipur (Sharma 2009a,b) of northeastern India.

To sum up, various new records support the importance of recent sampling of Deepor Beel, 155 species examined in our present collections reiterate the environmental heterogeneity of this interesting floodplain lake of India and our update on 171 species known till date from this Ramsar site impart it biodiversity value as one of the globally rich 
habitat for the taxon. Our plankton collections with bias towards planktonic and semi-planktonic taxa yet highlight lacunae on periphytic, sessile and benthic taxa vis-a-vis the rotifer associations with diverse aquatic macrophytes. We estimate occurrence of $220+$ rotifer species from this interesting ecotone following specific sampling and analysis of the stated communities.

\section{REFERENCES}

Dhanapathi, M.V.S.S.S. (1976). Rotifers from Andhra Pradesh, India. II. Euchlanis brahmae sp. nov. with taxonomic notes on Indian species of the genus Euchlanis Ehrenberg. Memoirs Society Zoology Guntur 1: 43-48.

Dhuru, S., B. Suresh \& B. Pilo (2003). Additions to the rotifer fauna of Gujarat. Journal of Aquatic Biology 18(1): 35-39.

Dumont, H.J. \& H. Segers (1996). Estimating lacustrine zooplankton species richness and complementarity. Hydrobiologia 341: 125-132.

Edmondson, W.T. \& G.E. Hutchinson (1934). Report on Rotatoria. Article IX. Yale North India expedition. Memoirs Connecticut Academy of Arts \& Sciences 10: 153-186

Fontaneto, D., A.M. Barbosa, H. Segers \& M. Pautasso (2012). The 'rotiferologist' effect and the other global correlates of species richness in rotifers. Ecography 35: 174-182.

Giri, F. \& S.J. De Paggi (2006). Geometric morphometric and biometric analysis for the systematic elucidation of Brachionus caudatus Barrois and Daday, 1894 (Rotifera Monogononta Brachionidae) forms. Zoologischer Anzeiger 244: 171-180.

Green, J. (2003). Associations of planktonic and periphytic rotifers in tropical swamp, the Okavango Delta, southern Africa. Hydrobiologia 490: 197-209.

Jersabek, C.D. \& M.F. Leitner (2013). The Rotifer World Catalog. World Wide Web electronic publication. http://www.rotifera.hausdernatur.at/, accessed on 03.12.2013.

Jithland, I. \& L. Wongrat (2006). Composition and distribution of zooplankton in the Pakak Jolasid Reservoir, Lop Buri Province. Khon Kaen University Fisheries Research Bulletin 30: 1-18.

Koste, W. (1978). ROTATORIA. Die Rädertiere Mitteleuropas, begründet von Max Voigt. Überordnung Monogononta. Gebrüder Borntraeger, Berlin Stuttgart. Text (673 pp) u. II. Tafelbd. (T. 234).

Meas, S. \& L. Sanoamuang (2010). New records of rotifer fauna in the Cambodian Mekong River Basin. Cambodian Journal of Natural History 1: 48-62.

Pourriot, R. (1996). Rotifers from Petit Saut reservoir (French Guyana), with the description of a new taxon. Hydrobiologia 331: 43-52.

Reid, J. \& P.N. Turner (1988). Planktonic Rotifera, Copepoda, and Cladocera from Lagos Acu and Viana, State of Maranhao, Brazil. Revue of Brasilian Biology 48: 485-495.

Sa-ardrit, P., P. Pholpunthin \& H. Segers (2013). A checklist of the freshwater rotifer fauna of Thailand (Rotifera, Monogononta, Bdelloidea). Journal of Limnology 72(2): 361-375.

Sanoamuang, L. (1998). Rotifera of some freshwater habitats in the floodplains of the River Nan, northern Thailand. Hydrobiologia 387/388: 27-33.

Sarma, S.S.S. (1988). New records of freshwater rotifers (Rotifera) from Indian waters. Hydrobiologia 160: 263-269.

Segers, H. (1995). Rotifera 2: Lecanidae. 6: 1-226. In: Dumont, H.J. \& T. Nogrady (eds.). Guides to identification of the Microinvertebrates of the Continental waters of the world. SPB Academic Publishing bv. Amsterdam, the Netherlands.

Segers, H. (2001). Zoogeography of the Southeast Asian Rotifera. Hydrobiologia 446/ 447: 233-246.

Segers, H. (2007). Annotated checklist of the rotifers (Phylum Rotifera), with notes on nomenclature, taxonomy and distribution. Zootaxa 1564 1-104.

Segers, H. \& H.J. Dumont (1996). 102+ rotifer species (Rotifera: Monogononta) in Broa reservoir (SP., Brazil) on 26 August 1994, with the description of three new species. Hydrobiologia 316: 183-197.

Segers, H., C.S. Nwadiaro \& H.J. Dumont (1993). Rotifera of some lakes in the floodplain of the river Niger (Imo State, Nigeria). II. Faunal composition and diversity. Hydrobiologia 250: 63-71.

Segers, H., N.L. Ferrufino \& L. De Meester (1998). Diversity and Zoogeography of Rotifera (Monogononta) in a flood plain lake of the Ichilo river, Bolivia, with notes on little known species. Internationale Revue Hydrobiologie 83: 439-448.

Sharma, B. K. (1998). Freshwater Rotifers (Rotifera: Eurotatoria). In: Fauna of West Bengal. State Fauna Series 3(11): 341-461. Zoological Survey of India, Calcutta.

Sharma, B.K. (2004). Rare and interesting monogonont rotifers (Rotifera, Eurotatoria) from North-Eastern India. Mitteilungen aus dem Museum für Naturkunde Berlin, Zoologische Reihe 80: 33-40.

Sharma, B.K. (2005). Rotifer communities of floodplain lakes of the Brahmaputra basin of lower Assam (N.E. India): biodiversity, distribution and ecology. Hydrobiologia 533: 209-221.

Sharma, B.K. (2009a). Diversity of Rotifers (Rotifera: Eurotatoria) of Loktak lake, North- Eastern India. Tropical Ecology 50(2): 277-285

Sharma, B.K. (2009b). Rotifer communities of floodplain lakes of Manipur (North-East India): biodiversity, distribution and ecology. Journal of Bombay Natural History Society 106(1): 45-56.

Sharma, B.K. (2014). Rotifers (Rotifera: Eurotatoria) from wetlands of Majuli - the largest river island, the Brahmaputra river basin of upper Assam, northeast India. Check List 10(2): 292-298.

Sharma, B.K. \& S. Sharma (1999). Freshwater Rotifers (Rotifera: Eurotatoria) In: State Fauna Series: Fauna of Meghalaya 4(9):11-161. Zoological Survey of India, Calcutta.

Sharma, B.K. \& S. Sharma (2000). Freshwater Rotifers (Rotifera: Eurotatoria). In: State Fauna Series: Fauna of Tripura 7 (4): 163-224. Zoological Survey of India, Calcutta.

Sharma, B.K. \& S. Sharma (2005a). Biodiversity of freshwater rotifers (Rotifera: Eurotatoria) from north-eastern India. Mitteilungen aus dem Museum für Naturkunde Berlin, Zoologische Reihe 81: 81-88.

Sharma, B.K. \& S. Sharma (2005b). Faunal diversity of rotifers (Rotifera: Eurotatoria) of Deepor beel, Assam (N.E. India) - a Ramsar site. Journal of Bombay Natural History Society 102(2): 169-175.

Sharma, B.K. \& S. Sharma (2009). Biodiversity and distribution of freshwater rotifers (Rotifera, Eurotatoria) of Tamil Nadu. Records of the Zoological Survey of India 109(3): 41-60.

Sharma, B.K. \& S. Sharma (2011). Deepor Beel revisited: new records of rotifers (Rotifera: Eurotatoria) with remarks on interesting species. Journal of Threatened Taxa 3(1): 1437-1444; http://dx.doi.org/10.11609/ JoT. $02482.1437-44$

Sharma, B.K. \& S. Sharma (2012). Deepor Beel-a Ramsar site of India: an interesting hot-spot with its rich Rotifera biodiversity. Acta Zoologica Academiae Scientiarum Hungaricae 58(2): 105-120.

Sharma, B.K. \& S. Sharma (2014a). Northeast India - an important region with a rich biodiversity of Rotifera. In: Rotifera XIII -Rotifer Biology: a Structural and Functional approach (Eds. B. K. Sharma, H.J. Dumont \& R. L. Wallace). International Review of Hydrobiology 99(1-2): 20-37; http:// dx.doi.org/10.1002/iroh.201301701

Sharma, B.K. \& S. Sharma (2014b). Indian Lecanidae (Rotifera: Eurotatoria: Monogononta) and its distribution. In: Rotifera XIII-Rotifer Biology: a Structural and Functional approach (Eds. B. K. Sharma, H.J. Dumont \& R. L. Wallace). International Review of Hydrobiology 99(1-2): 38-47; http:// dx.doi.org/10.1002/iroh.201301702

Sharma, B.K. \& S. Sharma (2014c). Floodplains of the Brahmaputra River basin-globally interesting ecotones with rich Rotifer (Rotifera: Eurotatoria) biodiversity, pp. 258-270. In: Sinha, R.K. \& B. Ahmed (eds.). Rivers for LifeProceedings of the International Symposium on River Biodiversity: GangesBrahmaputra - Meghna River System, Ecosystems for Life. A Bangladesh - India Initiative, International Union for Conservation of Nature.

Sharma, S. \& B.K. Sharma (2008). Zooplankton diversity in floodplain lakes of Assam. Records of the Zoological Survey of India, Occasional Paper No. 290: $1-307+28$ plates.

Sharma, S. \& B.K. Sharma (2013). Faunal Diversity of Aquatic Invertebrates of Deepor Beel (a Ramsar site), Assam, northeast India. Wetland Ecosystem Series 17: 1-227+15 plates, Zoological Survey of India, Calcutta. 
Appendix 1: Systematic list of total Rotifer taxa known from Deepor Beel

\section{Phylum: Rotifera}

Class: Eurotatoria

Subclass: Monogononta

\section{Order: Ploima}

Family: Brachionidae

1. Anuraeopsis fissa Gosse, 1851

2. A. navicula Rousselet, 1911

Brachionus ahlstromi Lindeman, 1939

Brachionus angularis Gosse, 1851

B. bidentatus Anderson, 1889

B. budapestinensis Daday, 1885

B. calyciflorus Pallas, 1766

B. caudatus Barrois \& Daday, 1894

B. dichotomus reductus Koste \& Shiel,1980

10. B. diversicornis (Daday, 1883)

11. B. donneri Brehm, 1851 \#

12. B. durgae Dhanapathi, 1974

13. B. falcatus Zacharias, 1898

14. B. forficula Wierzejski, 1891

15. B.kostei Shiel, 1983*

16. B. mirabilis Daday, 1897

17. B. quadridentatus Hermann, 1783

18. B. rubens Ehrenberg, 1838 \#

19. Keratella cochlearis (Gosse, 1851)

20. K. edmondsoni Ahlstrom, 1943

21. K. lenzi Hauer, 1953

22. K. procurva (Thorpe, 1891)

23. K. quadrata (O.F. Müller, 1786) \#

24. K. tecta (Gosse, 1851)

25. K. tropica (Apstein, 1907)

26. Platyias leloupi Gillard, 1957

27. P. quadricornis (Ehrenberg,1832

28. Plationus patulus (O.F. Müller, 1786)

\section{Family: Epiphanidae}

29. Epiphanes brachionus (Ehrenberg, 1837)

30. E. senta (O.F. Müller, 1773) \#

\section{Family: Euchlanidae}

31. Euchlanis dilatata Ehrenberg, 1832

32. E. incisa Carlin, 1939

33. E. meneta Myers, $1930 *$

34. E. triquetra Ehrenberg, 1838

35. Dipleuchlanis propatula (Gosse, 1886)

36. Tripleuchlanis plicata (Levander, 1894)

37. Beauchampiella eudactylota (Gosse, 1886)

\section{Family: Mytilinidae}

38. Lophocharis salpina (Ehrenberg,,1834)

39. Mytilina acanthophora Hauer, 1938

40. M. bisulcata (Lucks, 1912)

41. M. michelangellii Reid \& Turner, 1988 *

42. M. ventralis (Ehrenberg, 1830)

Family: Trichotriidae

43. Macrochaetus collinsi (Gosse, 1867)

44. M. longipes Myers, 1934

45. M. sericus (Thorpe, 1893)

46. Trichotria tetractis (Ehrenberg,1830)

47. Wolga spinifera (Western, 1894)*

\section{Family: Lepadellidae}

48. Colurella adriatica Ehrenberg, 1831*

49. C. colurus (Ehrenberg, 1830) *

50. C. obtusa (Gosse,1886)

51. C. sulcata (Stenroos, 1898) \#

52. C. uncinata (O.F. Müller, 1773)

53. Lepadella acuminata (Ehrenberg, 1894)

54. L. apsida Harring, 1916

55. L benjamini Harring, 1916

56. L. biloba Hauer, 1938

57. L. costatoides Segers, 1992

\author{
58. L. dactyliseta (Stenroos, 1898) \\ L. discoidea Segers, 1993 \\ L. elongata Koste, 1992 \\ L. eurysterna Myers, 1942 \\ 62. L.lindaui Koste, 1981 * \\ 63. L. minuta (Weber \& Montet, 1918) \\ 64. L. ovalis (O.F. Müller, 1786) \\ 65. L patella (O.F. Müller, 1773) \\ 66. L. quinquecostata (Lucks, 1912) * \\ 67. L. rhomboides (Gosse,1886) \\ 68. L. rhomboidula (Bryce, 1832) \# \\ 69. L. triba Myers, 1934 * \\ 70. L. triptera Ehrenberg, 1832 \\ 71. L. vandenbrandei Gillard, 1952 * \\ L. (H.) apsicora Myers, 1934 \\ L. (H.) ehrenbergi (Perty, 1850) \\ L. (H.) heterostyla (Murray, 1913) \\ 75. Squatinella mutica (Ehrenberg,1832)
}

Family: Lecanidae

76. Lecane aculeata (Jakubski, 1912)

77. L. arcula Harring, 1914

78. L. bifurca (Bryce, 1892) *

79. L. blachei Berzins, 1973

79. L. blachei Berzins, 1973

81. L. closterocerca (Schmarda, 1859)

82. L. crepida Harring, 1914

83. L. curvicornis (Murray, 1913)

84. L. decipiens (Murray, 1913)

85. L. doryssa Harring, 1914

86. L. elegans Harring, 1914

87. L. flexilis (Gosse,1886)

88. L. furcata (Murray, 1913)

89. L. haliclysta Harring \& Myers, 1926

90. L. hamata (Stokes, 1896)

91. L. hastata (Murray, 1913) \#

92. L. hornemanni (Ehrenberg,1834)

93. L. inermis (Bryce, 1892)

94. L. inopinata Harring \& Myers, 1926

95. L. lateralis Sharma, 1978

96. L. leontina (Turner, 1892)

97. L. ludwigii (Eckstein, 1883)

98. L. luna (O.F. Müller, 1776)

99. L. lunaris (Ehrenberg,1832)

100. L. monostyla (Daday, 1897)

101. L. nana (Murray, 1913)

102. L. nitida (Murray, 1913)

103. L. obtusa (Murray, 1913)

104. L. ohioensis (Herrick, 1885)

105. L. papuana (Murray, 1913)

106. L. paxiana Hauer, 1940

107. L. pertica Harring \& Myers, 1926 \#

108. L. ploenensis (Voigt, 1902)

109. L. pusilla Harring, 1914

110. L. pyriformis (Daday, 1905)

111. L. quadridentata (Ehrenberg, 1830)

112. L. rhenana Hauer, 1929 *

113. L. rhytida Harring \& Myers, 1926 *

114. L. signifera (Jennings, 1896)

115. L. sola Hauer, 1936 \#

116. L. stenroosi (Meissner, 1908)

117. L. sympoda Hauer,1929

118. L. tenuiseta Harring, 1914

119. L. thienemanni (Hauer,1938)

120. L. undulata Hauer, 1938 *

121. L. unguitata (Fadeev, 1925)

122. L. ungulata (Gosse,1887)

Family: Notommatidae

123. Cephalodella forficula (Ehrenberg, 1830)

124. C. gibba (Ehrenberg,1830)

125. C. mucronata Myers, 1934

126. Monommata longiseta (O.F. Müller, 1786)
127. Notommata spinata Koste \& Shiel, 1991 \# Family: Scaridiidae

128. Scaridium longicaudum (O.F. Müller, 1786)

Family: Gastropodidae

129. Ascomorpha saltans Bartsch, 1870

Family: Trichocercidae

130. Trichocerca bicristata (Gosse, 1887)

131. T. bidens (Lucks, 1912) \#

132. T. capucina (Wierzejski \& Zacharias, 1893)

133. T. cylindrica (Imhof, 1891)

134. T. elongata (Gosse,1886)

135. T. flagellata Hauer,1937

136. T. iernis (Gosse, 1887)

137. T. insignis (Herrick, 1885)

138. T. longiseta (Schrank, 1802

139. T. porcellus (Gosse, 1851)

140. T. pusilla (Jennings, 1903)

141. T. rattus (O.F. Müller, 1776)

142. T. scipio (Gosse, 1886) *

143. T. similis (Wierzejski, 1893)

144. T. sulcata (Jennings, 1894)

145. T. tigris (O.F. Müller, 1786)

146. T. weberi (Jennings, 1903) *

Family: Asplanchnidae

147. Asplanchna priodonta Gosse, 1850

Family: Synchaetidae

148. Polyarthra vulgaris Carlin, 1943

Family: Dicranophoridae

149. Dicranophoroides caudatus (Ehrenberg,1834)

150. Dicranophorus forcipatus (O.F. Müller, 1786)

\section{Order: Flosculariaceae}

Family: Floscularidae

151. Floscularia ringens (Linnaeus, 1758) \#

152. Lacinularia flosculosa (O.F. Müller, 1773) \#

153. Limnias ceratophylli Schrank, 1803 \#

154. Sinantherina socialis (Linne, 1758)

155. S. spinosa (Thorpe, 1893)

Family: Conochilidae

156. Conochilus unicornis Rousselet, 1892

Family: Hexarthridae

157. Hexarthra mira (Hudson, 1871)

Family: Testudinellidae

158. Testudinella brevicaudata Yamamoto, 1951 \#

159. T. emarginula (Stenroos, 1898)

160. T. greeni Koste, 1981

161. T. parva (Ternetz, 1892)

162. T. patina (Hermann, 1783)

163. Pompholyx sulcata Hudson, 1885

Family: Trochosphaeridae

164. Filinia brachiata (Rousselet, 1901) \#

165. F. camasecla Myers, 1938

166. F. longiseta (Ehrenberg,1834)

167. F. opoliensis (Zacharias, 1898)

168. F. pejleri Hutchinson, 1964

169. Trochosphaera aequatorialis Semper, 1872

\section{Sub-class: Digononta}

Family: Philodinidae

170. Rotaria neptunia (Ehrenberg,1830)

171. R. rotatoria (Pallas, 1766)

* New record from Deepor Beel; \# not observed in our present collections 